\title{
Duygusal Emek ile İş Stresi İlişkisinin İncelenmesi: Kamu Çalışanlarına Yönelik Bir Araştırma*
}

\author{
Hidayet YILDIZ** ${ }^{*}$ Merve KOÇOĞLU SAZKAYA***
}

Öz

$\mathrm{Bu}$ çalışma duygusal emek ve duygusal emek boyutları (yüzeysel davranış, derinlemesine davranış ve samimi davranış) ile iş stresi ve iş stresinin boyutları (endişe ve zaman stresi) arasındaki ilişkileri incelemek amacıyla İstanbul'da bir ilçe belediyesinde çalışan 347 beyaz yakalı iş gören üzerinde gerçekleștirilmiştir. Araștırmada veri toplama yöntemi olan anket tekniğinden yararlanılmıştır. Araștırmada elde edilen veriler SPSS programında nicel analiz yöntemleri kullanılarak analiz edilmiștir. Araștırma sonucuna göre duygusal emek ile iş stresi arasında pozitif ve anlamlı bir ilișki olduğu ortaya çıkmıștır. Bunun yanı sıra, duygusal emeğin boyutlarından olan yüzeysel davranıș ile iş stresi ve iş stresi boyutları olan endişe stresi ve zaman stresi arasında anlamlı ve pozitif ilișki olduğu fakat duygusal emek boyutu olan derinlemesine davranış ve samimi davranış ile iş stresi ve iş stresi boyutları olan endişe stresi ve zaman stresi arasında anlamlı ilişkiler olmadığı gözlemlenmiștir.

Anahtar Kelimeler: Duygusal Emek, Yüzeysel Davranış, İş Stresi, Kamu Çalıșanları, Belediye

\section{An Investigation of the Relationship between Emotional Labor and Job Stress: A Research within Public Employees}

\author{
Abstract \\ This study was conducted on 347 white-collar workers working in a district \\ municipality in Istanbul to examine the relationship between emotional labor and its \\ dimensions (surface acting, deep acting and naturally felt emotions) and job stress and its \\ dimensions (anxiety stress and time stress). In this research, questionnaire technique \\ which is a data collection method was used. The data were analyzed by using quantitative \\ analysis methods in SPSS program. The results of the study revealed that there is a

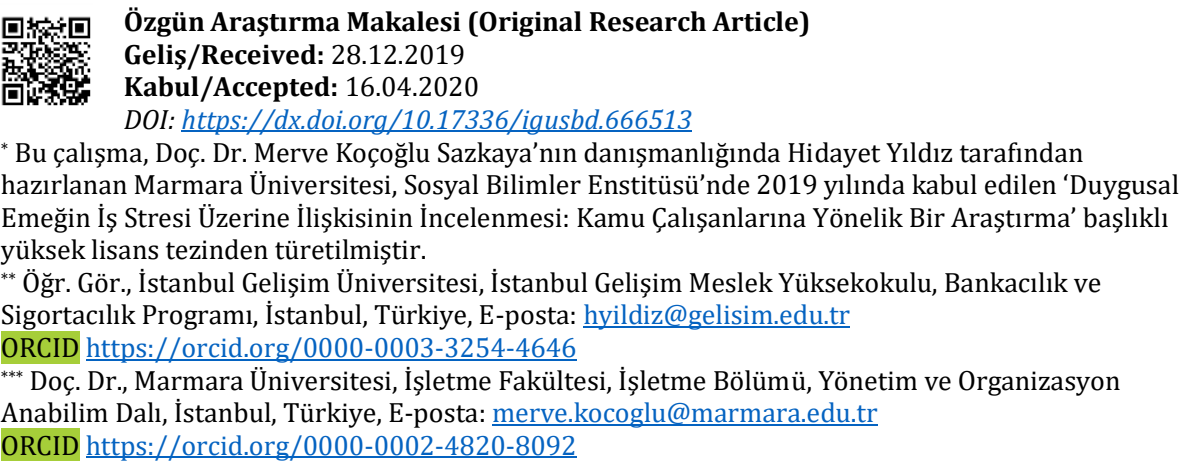


positive and significant relationship between emotional labor and job stress. Additionally, there are positive and significant relationships between surface acting (one of the dimensions of emotional labor) and job stress and its dimensions which are anxiety stress and time stress respectively. However, deep acting and naturally felt emotions (one of the dimensions of emotional labor) do not have significant relationships with job stress and its dimensions which are anxiety stress and time stress.

Keywords: Emotional Labour, Surface Acting, Job Stress, Public Employees, Municipality

\section{Giriş}

Günümüzde hizmet sektörü gün geçtikçe önem kazanmaktadır. Gelișen teknoloji ve bilgiye ulaşım hızı, müşteriye sunulacak ürünün çok hızlı bir şekilde tüm paydaşlar tarafından bilinir olmasını sağlamıștır. Bu durum, örgütlerin benzer mal ve hizmeti üretebildiği ve müşterisine sunabildiği bir rekabet ortamı yaratmıștır. Örgütler böyle bir ortamda kendilerine rekabet avantajı sağlayabilecek unsurlar olan hizmet kalitesi ve müşteri memnuniyeti kavramlarını ön plana çıkartmıștır. Müşteri memnuniyetini en üst düzeyde gerçekleștirmeyi planlayan örgütler, iş görenlerinin duygusal emeklerini de yönetme sürecine girmiştir. Bu doğrultuda örgütler müşterilerinde olumlu duygular uyandıracak duygusal gösterim kurallarını belirlemiş olup iş görenlerin bu kurallara uymasını beklemektedir. İş görenin hissetmediği fakat örgütün kendinden beklediği duygu durumunu gösterebilmek için harcadığı yoğun çaba duygusal emek olarak ifade edilmektedir (Hochschild, 1983, s. 7).

Örgütlerin beklentilerini gerçekleştirebilmek için yoğun duygusal emek harcaması iş gören üzerinde kimi zaman olumsuz sonuçlara neden olmaktadır. $\mathrm{Bu}$ sonuçlardan biri ise iş stresidir. İș stresi, iş gören ile çalıșma koșullarının karşılıklı etkileșimi sonucunda oluşan olumlu ve olumsuz özellikler içeren bir durum olarak tanımlanmaktadır (Landrum, Knight \& Flynn, 2011, s. 223; Ross \& Altmaier, 1994, s. 55). Rekabet avantajı elde etmek isteyen örgütler artan müșteri memnuniyet kriterlerini gerçekleştirebilmek için iş görenlerden daha fazla beklentiye girmektedirler. Bu durum ise iş görenlerde iş stresine neden olmaktadır. Bu bağlamda, duygusal emek davranışı iş stresini etkileyen önemli bir unsur olarak görülmektedir. İş görenlerin iş stresi ile karşı karşıya kalmaları hizmet verdiği müşterilere de olumsuz sonuçlar doğurmakta ve örgütün hedeflerini olumsuz etkilemektedir. Çağdaş yönetim anlayışında insan unsurunun en önemli kaynaklardan biri olduğu söylenebilir. Bu nedenle örgütlerin insan unsurunu hedefleri doğrultusunda yüksek verim alacak şekilde sürece dâhil edebilmesi için iş stresini azaltıcı önlemler alması gerekmektedir.

$\mathrm{Bu}$ bağlamda bu çalışmasının literatür bölümünde duygusal emek ve iş stresi kavramlarına yer verilecektir. Araştırma bölümünde ise İstanbul'da bir ilçe belediyesindeki iş görenlere yönelik araștırma yer alacaktır. İlgili yazın incelendiğinde duygusal emek ile iş stresi arasındaki ilişki ile ilgili birçok çalışma yapılmış (Akdu \& Akdu (2016); Karakaş \& Gökmen (2018); Kaya (2009); Sohn vd. (2018); Özgün (2015); Yoon \& Kim (2013) olmasına rağmen kamu kuruluşları üzerinde pek fazla çalışma yapılmadığı görülmüştür. $\mathrm{Bu}$ nedenle, bu çalışmanın konuyla ilgili yazına katkı sağlayacağı düşünülmektedir. Dolayısıyla, bu araştırmada duygusal emek ile iş stresi arasındaki ilişki ele alınacaktır. Aynı zamanda çalışmada duygusal emeğin alt boyutları (yüzeysel davranış, derinlemesine davranış ve samimi davranış) ile iş stresinin alt boyutları (zaman stresi ve endişe stresi) arasındaki ilişkilerde incelenecektir. 


\section{Literatür Taraması}

\subsection{Duygusal Emek Kavramı}

İş görenlerin hissettiği duygular ile örgütlerin beklediği duygular arasında farklılıklar oluşabilmektedir. Örgütlerin, iş görenden beklentisi onların hissettiği duyguları göstermesi değil, örgütün amaçlarına uygun olarak belirlenmiş duyguları göstermesidir. Bu durumda, iş görenlerden beklenen duygu durumunu gösterebilmesi için çaba göstermesi gerekmektedir. İş görenlerden beklenen bu çaba ise "duygusal emek" olarak ifade edilmektedir (Theodosius, 2008, s. 15). Bununla birlikte, örgütlerden hizmet alan kişilerin ikna olabilmesi zihinlerde oluşan olumlu algıya bağlıdır. Olumlu algıyı sağlayacak iş görenlerin, gerçek duygularını bastırarak yüz ifadelerini ve beden dilini örgütün isteklerine uygun olarak düzenlenmesi gerekmektedir. Bu durumda, iş görenin yaptığı düzenleme duygusal emek olarak tanımlanmaktadır (Hochschild, 1983, s. 7).

Duygusal emek kavramı, iş görenin örgüt tarafından uyulması beklenen ve kabul gören duyguları sergileme çabası olarak tanımlanmaktadır (Ashforth \& Humphrey, 1993, s. 90). Morris ve Feldman (1996, s. 987) duygusal emek kavramını, örgüt tarafından belirlenen ve istenen duyguları ifade etmek için harcanan çaba olarak tanımlamaktadır. Diğer bir tanımda ise duygusal emek, bireyin duygu ve hislerini örgütün amaç ve beklentileri için düzenlenmesi șeklinde ifade edilmiştir (Grandey, 2000, s. 97). Diefendorff ve Gosserand'a (2003, s. 945) göre ise duygusal emek, duygusal davranış kurallarının algılanması ve karşılaștırılması, bunun sonucunda gerçekleștirilen (sergilenen) duygusal davranışın, kurallarla farklılığın kontrol edilerek düzeltilmesidir.

Bir başka tanıma göre duygusal emek, iş görenlerin en iyi hizmeti sunabilmek için karşısındaki kişiyi anlayarak karşı tarafla empati yapması ve bu bağlamda gereken role uygun olarak sergilediği davranışları değiștirmesi veya duygu durumunu abartarak göstermesidir (Beğenirbaş \& Meydan, 2012, s. 164; Chu, 2002, s. 31).

Duygusal emek kavramına ilişkin literatür incelendiğinde, duygusal emek kavramı boyutlarının farklı şekilde kabul gördüğü gözlenmiştir. Duygusal emeğin, iki boyutlu (Karakaş, vd., 2016; Karakaş, 2017; Toprak, vd., 2015) ve üç boyutlu olarak çalışmalarda yer aldığı lakin literatürde daha çok üç boyutlu çalışmaların yapıldığı görülmektedir. Bunlar yüzeysel davranış, derinlemesine davranış ve samimi davranış șeklindedir (Jung \& Yoon, 2014, s. 49; Lee \& Ok, 2012, s. 1102; Matteson \& Miller, 2012, s. 178).

Duygusal emek kavramının boyutlarından olan yüzeysel davranış ilk defa Hochschild (1983)'in çalışmalarında görülmektedir. Yüzeysel davranış, iş görenin sahip olduğu duygu halini müşteriyi mutlu edecek şekilde göstermesi anlamına gelmektedir (Hochschild, 1983, s. 7). Bu davranış şeklinde, iş gören yaşadığı ruh halinden kopmadan ișletmelerin belirlemiş olduğu duygu durumlarına uygun davranış göstermektedir (Asforth \& Humphrey, 1993, s. 92; Brotheridge \& Grandey, 2002, s. 22; Grandey, 2000, s. 97). Yüzeysel davranışta kişiler beden dilini dikkatli kullanarak hissetmediği duyguları hissediyormuş gibi sergilemektedir. Bir başka ifadeyle, yüzeysel davranış, iş görenlerin gerçek duygularını maskeleyerek, karşı tarafa farklı duygular göstermesidir (Ashforth \& Humphrey, 1993, s. 92).

Derinlemesine davranış, iş görenin sergilemesi gereken duyguları örgütün istediği şekilde yansıtabilmek için kendi gerçek duygularını değiştirme sürecidir. Bir başka deyişle, derinlemesine davranışta duygular bastırılarak veya değiștirilerek, sergilenmesi gereken duygular hissedilmeye çalışılır. Derinlemesine davranış iki şekilde gösterilir. İlki, hissedilen duygunun bilinçli bir şekilde kontrol altına alınmasıdır. İkincisi ise, duyguların eğitilmesidir. Bu süreç, iş görenin göstereceği duygu ile ilgili daha önceki deneyimleri ve imgeleri düşünmesidir (Hochschild, 1983, s. 32). Derinlemesine davranış iş görenin karşısındakini kandırmak için önce kendisini kandırması olarak da ifade edilmektedir (Hochschild, 1983, s. 33). 
Derinlemesine davranışın yüzeysel davranıștan en temel farkı, iş görenin doğrudan duygulara yoğunlaşması ve bu duyguları değiştirebilmek için gayret göstermesidir (Yang \& Chang, 2008, s. 881). İş gören, derinlemesine davranışta hissettiği duyguları içeriden değiștirirken, yüzeysel davranışta dışarıdan değiștirmektedir (Chu, 2002, s. 19). Ayrıca iş gören, yüzeysel davranışta değiş̧meyen duygularını hissediyormuş gibi yaparken, derinlemesine davranışta duygularının değişmesini istemekte ve değiştirmektedir. Kısacası, bu durumda iş gören empati kurarak davranış göstermektedir (Schmidt \& Diestel, 2014, s. 1453)

Hochschild (1983)'in iki boyutlu yaklaşımına Ashforth ve Humprey (1993)'in katkıda bulunduğu ve daha sonra Diefendorff, Croyle ve Gosserand (2005)'in araştırmaları ile geliştirdikleri samimi davranış, duygusal emeğin üçüncü boyutu olarak eklenmiştir. Samimi davranış, çalışma sırasında iş görenlerin göstermiş olduğu davranışları gerçekten hissederek yapması şeklinde tanımlanmaktadır (Ashforth \& Humprey, 1993, s. 94; Diefendorff vd., 2005, s. 340).

Samimi davranış, örgütün iş görenlerden gerçekleștirmesini istediği davranışlar ile iş görenler tarafından sergilenen davranışların benzerlik göstermesidir. Örneğin, bir anaokulu öğretmenin çocuklara sevecen şefkatli ve sabırlı davranmasının nedeni çocukları çok sevmesi olabilir. Ayrıca hastası için üzülen bir doktor veya kötü hisseden müşterisi ile gerçekten ilgilenen bir barmen kendi gerçek duygularını gösterebilir. Örneklerde görüldüğü gibi işletmenin kendisinden beklediği davranış şeklini içtenlikle hissederek yapması samimi davranış olarak değerlendirilmektedir (Ashforth \& Humphrey, 1993 s. 94; Bağcl, 2015, s. 75).

Duygusal emek ile ilgili yapılan çalışmalar incelendiğinde, duygusal emeğin örgüt ve iş görenler açısından sonuçları olduğu görülmektedir (Kaya \& Özhan 2012, s. 114; Mengenci, 2015, s. 127). Örgütlerin amacına uygun olarak olușturulmuş davranış șekilleri iş görenleri karmaşık duygulardan uzak tutarak onların belirli sistematik davranış göstermelerini sağlamıștır. Örgütler tarafından düzenlenen duygulara iş görenlerin uyması belirli kurallar içerisinde tarafsız kalmalarını ve duygusal dengenin korunmasını, aynı zamanda örgüt içindeki ilişkilerin örgütlere daha faydalı ve verimli olmasını sağlamaktadır (Kaya \& Serçeoğlu, 2013, s. 317; Oral \& Köse, 2011, s. 473-474). Örgütün amacına uygun olarak duygusal emeğin düzenlenmesi, örgüt içerisinde bir düzen oluşturarak verim artışına neden olmaktadır (Eroğlu, 2010, s. 27; Yürür \& Ünlü, 2011, s. 87).

Müşterinin çok değerli olduğu süreçte, müşteride olumlu duygular uyandırabilen, bu duyguları sürekli hale getirebilen iş gören davranış şekillerinin örgütün imajına olumlu etkisi olduğu ifade edilmektedir. Olumlu duygusal davranışlar gösteren iş görenler, müşterilerin ürüne, örgüte olumlu duygular hissetmelerine ve aldığı hizmet kalitesini olumlu olarak algılamalarına ve örgüte karşı olumlu bir tutum göstermelerine neden olmaktadır (Özkan, 2011, s. 71).

\section{2. İş Stresi Kavramı}

Günümüz modern toplumlarında üretim ve tüketim süreçlerinde oluşan hızlı değişimler, çalışma ve sosyal hayata önemli oranda hareket ve hız getirmiştir. Böyle bir ortamda yaşayan bireyler, hızla gelișen ve değișen sosyal çevredeki değisşikliklere uyum sağlama sürecinde zorlanmaktadır. Bu nedenle bireyler stresle karşılaşmaktadır (Güney, 2016, s. 325; Örnek \& Aydın, 2008, s. 33).

Stres kavramının, Latince "estrica" ve Fransızca "estrece" sözcüklerinden türediği bilinmektedir. Stres kavramı, farklı zamanlarda çeşitli şekillerde adlandırılmıştır. Stres 17. yüzyılda insanları etkileyen olumsuz durumlar, felaket, musibet, dert, keder, vb. için 
kullanılırken, 18. ve 19. yüzyılda ise kavramın anlamı değişmiş güç, baskı ve zorluk anlamında kullanılmıștır (Yirik vd., 2014, s. 6223).

Stres, bireyin fazla çalışma çok az dinlenmeye dayalı fiziksel, zihinsel ve duygusal durumunda ve sosyal çevresinde meydana gelen pozitif veya negatif değişiklikler karşısında oluşturduğu tepkilerin bütünü olarak ifade edilmektedir (Griffits, 2010, s. 4).

Örgütlerde iş görenlerin karşılaştıkları stres, iş stresi olarak ifade edilmektedir. Literatürde iş stresi ile ilgili farklı tanımlar yapılmıştır. İş stresi, iş görenin yüksek arzular, sinırlamalar ve firsatlar nedeni ile hissettiği gerilim durumudur (Schermerhorn, 1989, s. 647). Bir başka tanıma göre iș stresi, bireyin kendisinden yapması istenen rol ve görevleri yapamaması sonucunda oluşan olumsuz psikolojik, fiziksel, duygusal tepkilerdir (Antonova, 2016, s. 10).

Farklı bir tanıma göre iş stresi, örgütlerin beklediği davranış şekillerinin, iş görenin sahip olduğu yeteneklerle örtüşmemesi nedeniyle, bireyde oluşan olumsuz fizyolojik ve psikolojik tepkiler olarak da ifade edilmektedir (Babatunde, 2013, s. 73). Erkoç'a (2006, s. 244) göre iş stresi, örgütlerde işle ilgili olarak hissedilen gerilimler, endişeler, kuşkular ve kaygılardır. İş stresi, iş görenin istemi ve kontrolü dışında oluşan olumsuz iș süreçlerinin sonunda meydana gelen, fiziksel ve psikolojik bir duruma girmesi olarak ifade edilmektedir (Judge ve Colquitt, 2004, s. 395). Başka bir ifadeyle, iş stresi, iş gören ile çalışma koşullarının karşılıklı etkileşimi sonucunda oluşan olumlu ve olumsuz özellikler içeren bir durum olarak da tanımlanmaktadır (Landrum vd. 2011, s. 223; Ross \& Altmaier, 1994, s. 55).

Bir başka tanıma göre iş stresi, iş görenin içinde bulunduğu sosyal ortamın beklentileri ile kendi inançları, değerleri, yetenekleri, gereksinimleri arasında oluşan duygusal uyumsuzluktan ve rol çatıșmasından kaynaklanan fiziksel ve sosyo-psikolojik bir gerilim halidir (Yüksel, 2003, s. 219).

İş gören, yoğun iş yaşamından ve örgütlerin beklentilerinden kaynaklanan farklı stres durumlarıyla karşılaşmaktadır. Örgütler iş görenlerden, hizmet sunarken gerçek hissettikleri duyguları değil, örgütün hedeflerine göre belirlenmiş gösterim kurallarına uygun davranış göstermesini beklemektedir. Hizmet sunarken duygusal emeğin boyutlarından olan yüzeysel davranışı yoğun olarak gösteren iş gören duygusal uyumsuzluk ve rol çatışması yaşamaktadır. Örgütün bu beklentisinin iş görenler üzerinde oluşturduğu baskı sonucu ortaya çıkan duygusal gerilimler ve çatışmalar da iş stresi olarak ifade edilmektedir (Altuntaş, 2003, s. 3-6; Broheridge \& Grandey, 2002, s. 25).

İş stresi kimi çalışmalarda tek boyutlu olarak ele alınmıştır. Parker ve DeCotiis (1983) tarafından iş stresini belirlemeye yönelik olarak geliştirilen ölçek ise başlangıçta tek boyut olarak ele alınmıştır. Fakat daha sonra yapılan çalışmalarda iş stresinin iki boyutlu olarak ele alınması gerektiği belirtilmiştir. Bu boyutlar endișe stresi ve zaman stresi olarak tanımlanmaktadır (Jamal, 1999, s. 153; Parker \& DeCotiis, 1983, s. 172).

Endișe ile ilgili literatürde birçok tanım yapılmıștır. Bunlardan bazıları; endișe, bireyi tehdit eden herhangi bir şeyin yol açtığı korku ve huzursuzluğu birleştiren, aynı zamanda hoş olmayan heyecansal bir durumun yaratılmasıdır (Cüceloğlu,1991, s. 277). Başka bir tanıma göre endișe, psikolojik bir gerginlik veya duygusal bir tepki olarak ifade edilmektedir (Nair, 2007, s. 47). Endișe, iş görende, kendi yerinde olmayı istememe bir başkasının yerinde olmayı isteme ve kendini unutma duygusunu yaratabilmektedir. Endişe, dengeli bir bilincin kişide yarattı̆̆ olumlu düşünceleri bertaraf ederek umutsuzluk, zayıflık gibi düşüncelerin oluşmasına ve gerçeklikten uzaklaşarak intihara kadar giden olumsuz bir süreci oluşturabilmektedir (Gall, 2006, s. 50-55). Bu bağlamda endişe stresi, yapılan iş ile ilgili iş görenin psikolojik ve fiziksel durumunu olumsuz etkileyen gerginlik ve kaygı olarak tanımlanmıştır (Netemeyer vd., 2005, s. 132). Nair (2007) tarafından endişe stresi, insan-çevre etkileşimlerinin sonucunda ortaya çıkan kaygı ve öfke gibi duyguların oluştuğu süreç olarak ifade edilmektedir (Nair, 2007, s. 42). 
Parker ve Decotiis'in (1983, s. 172) yaptığı çalışmada, endişe stresini oluşturan stres yapıcıları incelenmiş ve endișe stresini etkileyen boyutların, formaliteler (yapı, şartlar, bilgi) ve rol çatışması olduğu açıklanmıştır. Endişe stresi ile ilişkili en güçlü stres yapıcı unsurun rol çatışması olduğu belirtilmiştir.

Daha önce bahsedildiği üzere, iş stresi boyutlarından bir diğer zaman stresidir. Zaman ile ilgili birçok farklı tanım yapılmıştır. Zaman, Türk Dil Kurumu tarafından, "bir iş veya oluşun içinden geçtiği, geçeceği ya da geçmekte olduğu süre, vakit" olarak ifade edilmektedir (TDK, 2019). Örgütlerin en önemli kaynaklarından biri zamandır. Başka bir ifadeyle, yöneticilerin zamanları örgütsel yaşamın stratejik değerlerindendir. Örgütlerin hedeflerine ulaşabilmesi için, zaman boyutuna da iş gücü ve hammadde kadar özen gösterilmesi gerektiği belirtilmektedir (Önder, 1991, s. 25). Tüketilen zamanın yakalanması ve tasarruf edilmesi mümkün değildir. Belirli bir sürede gerçekleștirilmesi gereken hedefler ve yapılması gereken farklı görevler olması nedeniyle, zaman, iş gören için önemli bir stres kaynağı olabilmektedir. Bundan dolayı, yapılması gereken ișler, iş görende gerçekte olduğundan daha tehdit edici olarak algılanabilmektedir. Bu durumun, iş görende yarattığı olumsuz duygu hali zaman stresi olarak ifade edilmektedir (Onbaşıŏlu, 2004, s. 110). Parker ve Decotiis'in (1983, s. 175) yaptı̆̆ı çalışmada, zaman stresini oluşturan stres yapıcıları incelenmiș ve zaman stresini etkileyen boyutların; otonomi (işin kendisi), ücret ve performans ilişkisi (işin kendisi), iletişimdeki açıklık (yapı, şartlar, bilgi), yönetici desteği (ilişkiler) ve bağllık (ilişkiler) olduğu belirtilmiștir. Nair'in (2007) yaptığı çalışmada, zaman stresini iş stresinin bir boyutu olarak kategorize etmiştir ve iş taleplerinden birisi olan zaman baskısının birçok örgütte görüldüğü belirtilmiștir. Zaman baskısı gibi stres etkenlerinin, iş tutumları ve davranışlara etki ettiği belirtilmiştir (Nair, 2007, s. 133).

Yapılan bir araştırma sonucunda şu bulgulara ulaşılmıştır. Zaman stresinin endişenin anlamlı bir ön göstergesi olduğu ve zaman stresi ile endişe arasında anlamlı ve pozitif bir ilişkinin bulunduğu ifade edilmiştir (Nair, 2007, s. 107-109).

Örgütte yaşanan iş stresinin örgütün bütününü etkileyen olumsuz sonuçları olacağı belirtilmektedir. İş stresinin örgütsel sonuçları; düşük performans ve verimsiz çalışma, yanlış kararlar verme, iş yeri kazaları, işe yabancılaşma, iş yerine geç gelme, devamsızlık ve yüksek iş gören devir hızı şeklindedir (Durna, 2006, s. 323; Tutar, 2014, s. 257-258).

\section{Yöntem}

\subsection{Araştırmanın Önemi ve Amacı}

Günümüzde örgütlerin müşterilerine sunmuş oldukları ürün ve hizmetler her geçen gün daha da benzeşmektedir. Bu durum örgütlerin müşteri odaklı çalışmalarını zorunlu kılmıştır. Özellikle hizmet sektöründe müşteri odaklı çalışmanın önemli bir rekabet avantajı sağlaması iş görenlerin, kendilerine verilen görevleri yerine getirirken duygusal olarak da emek harcamalarını gerektirmektedir.

Diğer taraftan, günden güne artan rekabet koşullarl, müşteri memnuniyet kriterlerinin artmasına neden olmakta bu durum da örgütlerin, iş görenlerden beklentisini yükselterek iş görenler üzerinde baskı oluşturabilmektedir. Bu durum insanların iş stresi ile karşı karşıya kalmalarına neden olabilmektedir. İş görenin yoğun stres altında çalıșması, hizmet verdiği müșterilerde olumsuz etkiler yaratabilmekte ve örgütü olumsuz etkileyebilmektedir.

$\mathrm{Bu}$ nedenle örgütler, müşteri memnuniyetini arttırarak rekabet avantajı sağlayabilmek için iş görenlerin müşterilerle etkileşimleri sırasında sergilemeleri beklenen duygusal gösterim kurallarını belirlemektedir. İş görenlerin müșterilere hizmet sunmaları sırasında hissetmedikleri duyguları hissediyormuş gibi sergilemeleri, yoğun 
bir duygusal emek davranışı göstermesine neden olmaktadır. Ayrıca, bu durum iş görenler üzerinde olumsuz sonuçlar doğurmaktadır. Bu olumsuz sonuçlardan biri iş stresidir. Bir başka ifadeyle, iş görenlerin sergiledikleri duygusal emek davranışları yaşadıkları iş stresi düzeylerini etkilemektedir.

Ulusal ve uluslararası yazın incelendiğinde, duygusal emek ve iş stresi ilișkisi ile ilgili birçok alanda çalışma yapılmıș (Akdu \& Akdu (2016); Karakaş \& Gökmen, (2018); Kaya (2009); Sohn vd. (2018); Özgün (2015); Yoon \& Kim (2013) olmasına rağmen kamu kuruluşlarına yönelik pek fazla çalışma yapılmadığı görülmüştür. Bu nedenle, bu çalışmanın konuyla ilgili yazına katkı sağlayacağı düşünülmektedir. Dolayısıyla, bu çalışmanın amacı belediye iş görenlerinin duygusal emek davranışları (yüzeysel davranıș, derinlemesine davranış ve samimi davranış) ile iş stresi (zaman stresi ve endişe stresi) arasındaki ilişkiyi ortaya koymaktır.

\subsection{Araștırmanın Kapsamı}

Araştırma kapsamına İstanbul'da bulunan bir belediyenin ana merkez binasında görev yapan iş görenler alınmıștır. Bahsi geçen belediyenin insan kaynakları yöneticileri ile 2019 yılı Ocak ayında görüşülmüş ve toplamda 540 iş görenin belediyede çalıştığı bilgisi edinilmiştir.

Ana kütle üzerinden örnek kütle hesabına göre 540 örnek büyüklüğü yüzde 95 güven sınırları içerisinde ve yüzde 5 anlamlılık düzeyinde 240 olduğu hesaplanmıştır. Belediye iş görenleri ile birebir görüşme yolu ile anket paylaşılmış, gönüllülük esasına göre uygulama gerçekleştirilmiştir. Bu doğrultuda tüm iş görenlerle anket paylaşılmış olup araştırmanın örneklemini 347 kişi oluşturmaktadır.

Araştırmada belediye iş görenlerinin tercih edilme sebebi, belediye iş görenlerinin vatandaşlar ile direkt temas halinde hizmet vermeleridir. Günümüzde Belediyeler vatandaş memnuniyetinin sağlanabilmesi için belirlenmiş olan kuralları iş görenleri tarafından göstermelerini beklemektedir. Hissetmedikleri duyguları belediyenin beklentileri doğrultusunda sergilemek zorunda olmaları da iş görenler üzerinde iș stresine neden olmaktadır. Dolayısıyla, belediye iş görenlerinin iş stresine maruz kalacağı düşüncesiyle bu çalışma belediyede gerçekleştirilmiştir.

\subsection{Araștırmanın Değişkenleri, Modeli ve Hipotezleri}

Araştırma amacında geliştirilen model duygusal olaylar teorisine dayanmaktadır. Duygusal Olaylar Teorisi (DOT), örgütlerdeki duygusal durumların yapısını, nedenlerini ve sonuçlarını inceleyen teoridir. Duygusal olaylar teorisinde, iş görenin örgütte yaşadığı duygusal olayların çalışanın tutum ve davranışlarını etkilediği belirtilmektedir. $\mathrm{Bu}$ bağlamda da iş görenin örgütte yaşadığı duygusal emek ve iş stresi duygusal olaylar teorisine dayandırılmaktadır (Weiss \& Cropanzano, 1996, s. 11-12).

Araştırmanın değişkenlerinden biri yüzeysel davranış, derinlemesine davranış ve samimi davranış boyutlarından oluşan duygusal emek olup bir diğer değișkeni ise zaman stresi ve endișe stresi boyutlarından oluşan iş stresidir.

Araştırmanın modeli Şekil 1'de gösterildiği gibi, duygusal emek ile iş stresi arasındaki ilişkiyi belirlemek amacıyla oluşturulmuştur. 


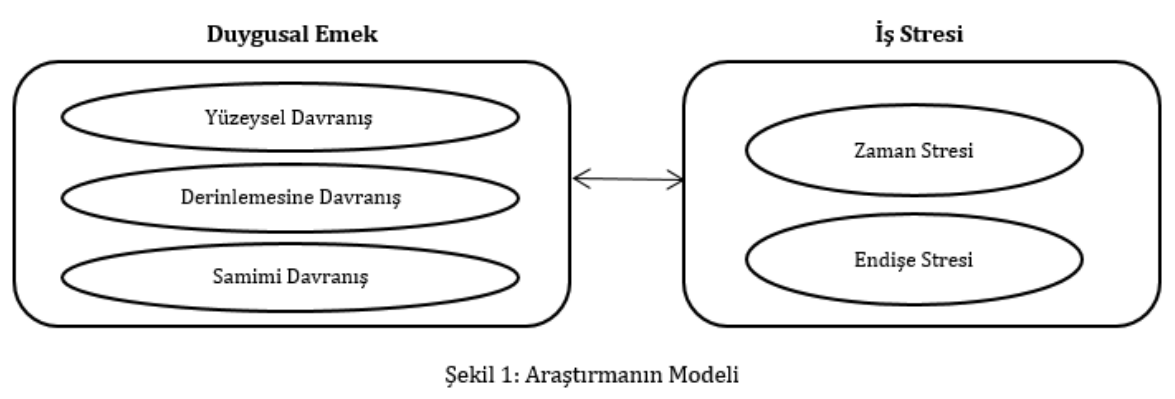

Araştırmada duygusal emek ile iş stresi arasındaki ilişkinin saptanması amacıyla aşağıdaki $\mathrm{H}_{1}$ hipotezi ve bu hipotez doğrultusunda alt hipotez kurulmuştur:

$\mathrm{H}_{1}$ : Duygusal emek ile iş stresi arasında ilişki vardır.

$\mathrm{H}_{1 \mathrm{a}}$ : Duygusal emeğin boyutları (yüzeysel davranış, derinlemesine davranış ve samimi davranış) ile iş stresi boyutları (zaman stresi ve endișe stresi) arasında ilişki vardır.

\subsection{Değişkenlere İlişkin Ölçme Araçları}

Çalışmada kullanılan ölçekler, detaylı literatür taramasından sonra belirlenmiş ve geçerliliği kanıtlanmış ölçeklerdir. Bu çalışmada duygusal emek ve iş stresi ölçekleri kullanılmıştır.

Araştırmada Diefendorff vd. (2005) tarafından geliştirilen duygusal emek ölçeği kullanılmıştır. Duygusal emek ölçeği yüzeysel davranış (7 ifade: 1, 2, 3, 4, 5, 6 ve 7), derinlemesine davranış (4 ifade: $8,9,10$ ve 11 ) ve samimi davranıș (3 ifade: 12, 13 ve 14) olmak üzere üç boyut ve 14 ifadeden oluşmaktadır. Duygusal emek ölçeğinde yer alan 7 . ifade "Vatandaşlarla ilgilenirken sergilediğim duygularda gerçeği yansıtmam." ters yönlü ifade olup bu ifadede puanlama tersine yapılmıştır. Ölçeğin Türkçe'ye çevirisinde Basım ve Beğenirbaş'ın (2012) çalışmasından yararlanılmıştır.

Katılımcıların iş stresini belirlemeye yönelik, Parker ve Decotiis (1983) tarafından geliştirilen 13 ifade "endișe/kaygı (anxiety)" ve "zaman stresi (time stress)" olmak üzere iki boyuttan oluşan ölçekten yararlanılmıștır. Orijinal ölçekte yer alan 1., 3., 5., 7. ve 10. ifadeler endișe boyutuna; 2., 4., 6., 8., 9., 11., 12. ve 13. ifadeler ise zaman stresi boyutuna yöneliktir. Yapılan literatür taramasında bahsi geçen ölçeğin araştırmacılar tarafından 9 ifadeden oluşan kısa formu kullandıkları tespit edilmiș olup bu çalışmada da 9 ifadeden oluşan kısa form kullanılmıștır (Aydın, 2018; Jamal \& Baba, 1992; Koçoğlu, 2014; Fields, 2002; Nair, 2007). Ölçeğin kısa formu orijinal ölçekte yer alan 1. 3. 5. 7. 9.10.11.12 ve 13. ifadelerden oluşmaktadır. Ölçekte yer alan 1., 2., 3., 4. ve 6. ifadeler endişeye yönelik; 5., 7., 8. ve 9. ifadeler ise zaman stresine yöneliktir. Ölçeğin Türkçe'ye çevirisinde Koçoğlu'nun (2014) çalışmasından yararlanılmıştır.

Anketin son bölümünde ise katılımclların demografik özelliklerini belirlemek amacıyla cinsiyet, yaş, eğitim durumu, pozisyon, medeni durum, çocuk sahibi olma, çalışma hayatı kıdemi, mevcut yöneticiyle çalışma süresi ve kurum kıdemlerini belirlemeye yönelik ifadeler bulunmaktadır.

Anket formu, demografik ifadeler haricinde, 5'li likert ölçeğine göre derecelendirilmiştir. 5'li likert ölçeğine göre derecelendirmeler; Kesinlikle Katılmıyorum (1), Katılmıyorum (2), Kısmen Katılıyorum (3), Katılıyorum (4), Kesinlikle Katıllyorum (5) şeklinde sıralanmıştır. 


\section{Bulgular}

\subsection{Katılımcıların Demografik Özelliklerine İlişkin Bulgular}

Bu bölümde araștırmaya katılan katılımcıların demografik özelliklerine ilişkin bilgiler Tablo 1'de gösterilmiștir.

\begin{tabular}{|c|c|c|}
\hline Demografik Özellikler & Frekans (N) & Yüzde (\%) \\
\hline \multicolumn{3}{|l|}{ Cinsiyet } \\
\hline Kadın & 199 & 57,3 \\
\hline Erkek & 148 & 42,7 \\
\hline \multicolumn{3}{|l|}{ Yaş } \\
\hline $18-25$ & 33 & 9,5 \\
\hline $26-30$ & 64 & 18,4 \\
\hline 31-35 & 51 & 14,7 \\
\hline $36-40$ & 61 & 17,6 \\
\hline 41-50 & 75 & 21,6 \\
\hline 51 ve üzeri & 63 & 18,2 \\
\hline \multicolumn{3}{|l|}{ Eğitim Durumu } \\
\hline İlköğretim & 13 & 3,8 \\
\hline Lise & 76 & 21,9 \\
\hline Lisans & 116 & 33,4 \\
\hline Yüksek Lisans & 142 & 40,9 \\
\hline \multicolumn{3}{|l|}{ Pozisyon } \\
\hline Yönetici & 54 & 15,6 \\
\hline Çalışan & 293 & 84,4 \\
\hline \multicolumn{3}{|l|}{ Medeni Durumu } \\
\hline Evli & 224 & 64,5 \\
\hline Bekâr & 123 & 35,5 \\
\hline \multicolumn{3}{|l|}{ Çocuk Durumu } \\
\hline Var & 194 & 55,9 \\
\hline Yok & 153 & 44,1 \\
\hline \multicolumn{3}{|l|}{ Çalışma hayatı kıdemi } \\
\hline 1-5 yıl & 60 & 17,3 \\
\hline 6-10 yll & 77 & 22,2 \\
\hline 11-15 yıl & 58 & 16,7 \\
\hline $16-20$ yil & 45 & 13 \\
\hline 21-30 yil & 80 & 23 \\
\hline 31 ve üzeri & 27 & 7,8 \\
\hline \multicolumn{3}{|c|}{ Mevcut Yönetici ile Çalıșma } \\
\hline Süresi & 42 & 12,1 \\
\hline 1 yll & 117 & 33,7 \\
\hline $2-3$ yıl & 133 & 38,3 \\
\hline 4-5 yil & 16 & 4,7 \\
\hline 6-7 yil & 39 & 11,2 \\
\hline 8 yıl ve üzeri & & \\
\hline \multicolumn{3}{|l|}{ Belediyede Çalışma Süresi } \\
\hline 1 yıl & 28 & 8,1 \\
\hline $2-3$ yil & 58 & 16,7 \\
\hline 4-5 yil & 95 & 27,4 \\
\hline 6-7 yil & 32 & 9,2 \\
\hline 8 ve üzeri & 134 & 38,6 \\
\hline
\end{tabular}


Araştırma kapsamına alınan 347 katılımcının demografik verileri incelendiğinde, katılımcıların \%57,3'ü kadın, \%42,7'si erkek, \%9,5'i 18-25 yaş aralığında, \%18,4'ü 26-30 yaș aralığında, \%14,7'si 31-35 yaş aralığında, \%17,6'sı 36-40 yaş aralığında, \%21,6'sı 4150 yaş aralığında ve \%18,2'si 51 yaş ve üzerindedir. Anket cevaplarına göre katılımcıların \%3,8'i ilköğretim, \%21,9'u lise, \%33,4'ü lisans, \%40,9'u yüksek lisans mezunudur. Katılımcıların \%15,6'sı yönetici, \%84,4'ü çalışandır. Ankete katılanların \%64,5'i evli olup \%55,9'u çocuk sahibidir. Katılımcıların \%17,3'ü 1-5 yıl, \%22,2'si 6-10 yll, \%16,7'si 11-15 yıl, \%13'ü 16-20 yıl, \%23'ü 21-30 yll, \%7,8'i 31 yıl ve üzerinde çalışma hayatı kıdemine sahip olduklarını belirtmişlerdir. Ankete katılanların \%12,1'i 1 yıl, \%33,7'si 2-3 yıl, $\% 38,3$ 'ü 4-5 yll, \%4,7'si 6-7 yıl ve \%11,2'si 8 yll ve üzerinde mevcut yöneticisi ile çalıșmakta olduğunu ifade etmiştir. Katılımcıların \%8,1'i 1 yll, \%16,7'si 2-3 yıl, \%27,4'ü 45 yıl, \%9,2'si, 6-7 yıl, \%38,6'sı ise 8 yıl ve üzerinde kurum kıdemine sahip olduklarını ifade etmişlerdir.

\subsection{Geçerlilik ve Güvenilirlik Analizleri}

Araştırmanın bu bölümünde duygusal emek ve iş stresi ölçeklerine ilişkin geçerlilik ve güvenilirlik analizleri yer almaktadır.

\subsubsection{Duygusal Emek Ölçeğine İlişkin Geçerlilik ve Güvenilirlik Analizleri}

Duygusal emek ölçeğine uygulanan geçerlilik analizi sonucunda KMO değeri 0,83 olup KMO değeri 1'e yakındır. Bu sebeple elde edilen veri grubu, geçerlilik analizi için uygundur. Barlett testi 0,000 olarak anlamlı çıkmıştır (Durmuş vd., 2011, s. 80).

Duygusal emek ölçeğine uygulanan geçerlilik analizi sonucunda yüzeysel davranış boyutunun 7. ifadesinin ("Vatandaşla ilgilenirken sergilediğim duygularda gerçeği yansıtmam.") faktör yükü 0,50'nin altında kaldığı için analizden çıkarılmıştır (Durmuş vd., 2011, s. 85).

Duygusal emek ölçeğini analiz etmek için varimax rotasyon yöntemi kullanılarak geçerlilik analizi uygulanmıştır. Ölçek, orijinal ölçekteki gibi, Tablo 2'de görüldüğü üzere, 3 alt boyutlu yapı oluşturmuştur.

\begin{tabular}{|c|c|c|c|}
\hline Duygusal Emek İfadeleri & 1 & 2 & 3 \\
\hline $\begin{array}{l}\text { YD2: "Vatandaşla etkileşimdeyken iyi hissediyormuşum } \\
\text { gibi yaparım." }\end{array}$ & 0,81 & & \\
\hline $\begin{array}{l}\text { YD1: "Vatandaşla uygun bir şekilde ilgilenebilmek için rol } \\
\text { yaparım." }\end{array}$ & 0,81 & & \\
\hline $\begin{array}{l}\text { YD4: “İşim için göstermem gereken duyguları } \\
\text { hissediyormuş gibi davranırım." }\end{array}$ & 0,77 & & \\
\hline $\begin{array}{l}\text { YD5: "Mesleğimin gerektirdiği duyguları sergileyebilmek } \\
\text { için bir maske takarım." }\end{array}$ & 0,74 & & \\
\hline $\begin{array}{l}\text { YD3: "Vatandaşla etkileşimdeyken bir "şov" ya da } \\
\text { "performans" sergilerim." }\end{array}$ & 0,72 & & \\
\hline $\begin{array}{l}\text { YD6: "Vatandaşa içimde hissettiğim duygulardan farklı } \\
\text { duygular sergilerim." }\end{array}$ & 0,62 & & \\
\hline $\begin{array}{l}\text { DD3: "Vatandaşlara göstermem gereken duyguları } \\
\text { hissedebilmek için elimden geleni yaparım." }\end{array}$ & & 0,87 & \\
\hline $\begin{array}{l}\text { DD2: "Başkalarına göstermem gereken duyguları gerçekte } \\
\text { de hissetmek için çaba harcarım." }\end{array}$ & & 0,87 & \\
\hline
\end{tabular}


DD4: “Vatandaşlara sergilemem gereken duyguları içimde $\quad 0,86$ de geliştirmeye çalışırım."

DD1: “Vatandaşa göstermek zorunda olduğum duyguları $\quad 0,74$ gerçekten yaşamaya çalışırım."

SD2: “Vatandaşlara gösterdiğim duygular doğal olarak $\quad 0,88$ içimden gelir."

SD3: "Vatandaşlara gösterdiğim duygular o an hissettiklerimle uyumludur."

SD1: "Vatandaşlara ifade ettiğim duygular samimidir."

\begin{tabular}{|c|c|c|c|}
\hline Açıklanan Varyans & 26,4 & 22,3 & 18,1 \\
\hline Toplam Açıklanan Varyans & & 66,8 & \\
\hline
\end{tabular}

YD: Yüzeysel Davranış; DD: Derinlemesine Davranış; SD: Samimi Davranış

Tablo 2: Duygusal Emek Ölçeğine İlişkin Geçerlilik Analizi Sonuçları

6 ifadeden oluşan birinci alt boyut olan yüzeysel davranış ifadelerinin faktör yüklerinin 0,81 ile 0,62 arasında, 4 ifadeden oluşan ikinci alt boyut olan derinlemesine davranış ifadelerinin faktör yüklerinin 0,87 ile 0,74 arasında ve 3 ifadeden oluşan üçüncü alt boyut olan samimi davranış ifadelerinin faktör yüklerinin 0,88 ile 0,80 arasında olduğu görülmektedir. 13 ifadeden oluşan duygusal emek ölçeğine ait toplam açıklanan varyans ise 66,8'dir.

Duygusal emek ölçeğinin Cronbach alfa değeri $0,75^{\prime}$ dir. Duygusal emeğin alt boyutlarının Cronbach alfa değerleri ise yüzeysel davranış için 0,72, derinlemesine davranış için 0,87 ve samimi davranış için 0,83 'tür. Bu veriler doğrultusunda duygusal emek ölçeği güvenilir kabul edilmektedir (Cronbach, 1951).

Dolayısıyla, uygulanan geçerlilik ve güvenilirlik analizleri sonucunda ölçek orijinal ölçekteki gibi 3 boyutlu bir yapı oluşturmuştur.

\subsection{2. İş Stresi Ölçeğine İlişkin Geçerlilik ve Güvenilirlik Analizleri}

İş stresi ölçeğine uygulanan geçerlilik analizi sonucunda KMO değeri 0,83 olup KMO değeri 1'e yakındır. Bu sebeple elde edilen veri grubu, geçerlilik analizi için uygundur. Barlett testi 0,000 olarak anlamlı çıkmıștır (Durmuş vd., 2011, s. 80).

İş stresi ölçeğine uygulanan geçerlilik analizi sonucunda endișe stresi boyutunun 5. ifadesinin ("İşten izin aldığım zaman kendimi suçlu hissediyorum.") faktör yükü 0,50'nin altında kaldığı için analizden çıkarılmıştır (Durmuş vd., 2011, s. 85).

İş stresi ölçeğini analiz etmek için varimax rotasyon yöntemi kullanılarak geçerlilik analizi uygulanmıştır. Ölçek, orijinal ölçekteki gibi, Tablo 3'te görüldüğü üzere 2 alt boyutlu yapı oluşturmuştur.

\begin{tabular}{|c|c|c|}
\hline İș Stresi İfadeleri & 1 & 2 \\
\hline ZS3: “Sanki hiç izin kullanmamış gibi hissediyorum." & 0,78 & \\
\hline $\begin{array}{l}\text { ZS4: "Şirketimde benimle aynı seviyede çalışan birçok insan } \\
\text { işin gereklilikleri yüzünden tükenmiştir." }\end{array}$ & 0,75 & \\
\hline $\begin{array}{l}\text { ZS2: "Bazen evde telefonun çalmasından arama işle ilgili } \\
\text { olabilir diye korkuyorum." }\end{array}$ & 0,64 & \\
\hline ZS1: "Çok fazla işim ve bu işleri yapacak çok az zamanım var." & 0,58 & \\
\hline ES3: "İşimin beni çıldırttığı çok zaman olmuştur." & & 0,80 \\
\hline ES2: "İşim beni olması gereğinden daha fazla rahatsız ediyor." & & 0,75 \\
\hline
\end{tabular}


ES1: “İşim nedeniyle huzursuz ya da sinirli hissettiğim $\quad 0,64$

olmuştur."

ES4:“Bazen işimi düşündüğümde, göğsümde bir sıkıntı $\quad 0,63$

hissediyorum."

\begin{tabular}{lc}
\hline Açıklanan Varyans & 28,3 \\
Toplam Açlklanan Varyans & 56,5 \\
\hline
\end{tabular}

ES: Endișe Stresi; ZS: Zaman Stresi

Tablo 3. İş Stresi Ölçeğine İlişkin Geçerlilik Analizi Sonuçları

4 ifadeden oluşan birinci alt boyut olan zaman stresi ifadelerinin faktör yüklerinin 0,78 ile 0,58 arasında, 4 ifadeden oluşan ikinci alt boyut olan endișe stresi ifadelerinin faktör yüklerinin 0,80 ile 0,63 arasında olduğu görülmektedir. 8 ifadeden oluşan iş stresi ölçeğine ait toplam açlklanan varyans ise 56,5 'dir.

İş stresi ölçeğinin Cronbach alfa değeri 0,80'dir. İș stresinin alt boyutlarının Cronbach alfa değerleri ise zaman stresi için 0,71 ve endișe stresi için 0,72 'dir. Bu veriler doğrultusunda iş stresi ölçeği güvenilir kabul edilmektedir (Cronbach, 1951).

Dolayısıyla, uygulanan geçerlilik ve güvenilirlik analizleri sonucunda ölçek orijinal ölçekteki gibi 2 boyutlu yapı oluşturmuştur.

\subsection{Değişkenlere İlişkin Tanımlayıcı İstatistikler}

$\mathrm{Bu}$ bölümde, araştırmanın değişkenlerine ilișkin ortalama, standart sapma, basıklık ve çarpıklık değerleri yer almaktadır. Değişkenlerdeki ifadeler 5'li likert ölçeğine göre derecelendirilmiştir.

\begin{tabular}{|c|c|c|c|c|}
\hline Duygusal Emek İfadeleri & $\begin{array}{l}\text { İfadelere } \\
\text { İlişkin } \\
\text { Ortalama } \\
\text { Değerler }\end{array}$ & $\begin{array}{l}\text { Standart } \\
\text { Sapma }\end{array}$ & $\begin{array}{l}\text { Basıklık } \\
\text { Değerleri }\end{array}$ & $\begin{array}{l}\text { Çarpıklık } \\
\text { Değerleri }\end{array}$ \\
\hline $\begin{array}{l}\text { YD1: "Vatandaşla uygun bir } \\
\text { şekilde ilgilenebilmek için rol } \\
\text { yaparım." }\end{array}$ & 2,18 & 1,20 & $-0,509$ & 0,701 \\
\hline $\begin{array}{l}\text { YD2: "Vatandaşla } \\
\text { etkileşimdeyken iyi } \\
\text { hissediyormuşum gibi } \\
\text { yaparım." }\end{array}$ & 2,39 & 1,25 & -1.058 & 0,401 \\
\hline $\begin{array}{l}\text { YD3: "Vatandaşla } \\
\text { etkileşimdeyken bir "şov" ya da } \\
\text { "performans" sergilerim." }\end{array}$ & 2,04 & 1,61 & $-0,022$ & 0,959 \\
\hline $\begin{array}{l}\text { YD4: “İşim için göstermem } \\
\text { gereken duyguları } \\
\text { hissediyormuş gibi } \\
\text { davranırım.” }\end{array}$ & 2,36 & 1,23 & $-0,874$ & 0,508 \\
\hline $\begin{array}{l}\text { YD5: "Mesleğimin gerektirdiği } \\
\text { duyguları sergileyebilmek için } \\
\text { bir maske takarım." }\end{array}$ & 2,07 & 1,14 & $-0,402$ & 0,784 \\
\hline $\begin{array}{l}\text { YD6: "Vatandaşa içimde } \\
\text { hissettiğim duygulardan farklı } \\
\text { duygular sergilerim." }\end{array}$ & 2,26 & 1,21 & $-0,501$ & 0,550 \\
\hline
\end{tabular}




\begin{tabular}{|c|c|c|c|c|}
\hline Yüzeysel Davranıș & 2,22 & 1,27 & & \\
\hline $\begin{array}{l}\text { DD1: “Vatandaşa göstermek } \\
\text { zorunda olduğum duyguları } \\
\text { gerçekten yaşamaya çalışırım." }\end{array}$ & 3,17 & 1,25 & $-0,941$ & $-0,290$ \\
\hline $\begin{array}{l}\text { DD2: "Başkalarına göstermem } \\
\text { gereken duyguları gerçekte de } \\
\text { hissetmek için çaba harcarım." }\end{array}$ & 3,20 & 1,20 & $-0,903$ & $-0,278$ \\
\hline $\begin{array}{l}\text { DD3: “Vatandaşlara göstermem } \\
\text { gereken duyguları } \\
\text { hissedebilmek için elimden } \\
\text { geleni yaparım.” }\end{array}$ & 3,46 & 1,21 & $-0,681$ & $-0,535$ \\
\hline $\begin{array}{l}\text { DD4: “Vatandaşlara sergilemem } \\
\text { gereken duyguları içimde de } \\
\text { geliștirmeye çalıșırım.” }\end{array}$ & 3,38 & 1,19 & $-0,707$ & $-0,463$ \\
\hline Derinlemesine Davranıș & 3,30 & 1,21 & & \\
\hline $\begin{array}{l}\text { SD1: "Vatandaşlara ifade } \\
\text { ettiğim duygular samimidir." }\end{array}$ & 4,04 & 0,99 & 1.113 & -1.128 \\
\hline $\begin{array}{l}\text { SD2: "Vatandaşlara gösterdiğim } \\
\text { duygular doğal olarak içimden } \\
\text { gelir." }\end{array}$ & 3,89 & 1,05 & 0,384 & $-0,870$ \\
\hline $\begin{array}{l}\text { SD3: "Vatandaşlara gösterdiğim } \\
\text { duygular o an hissettiklerimle } \\
\text { uyumludur." }\end{array}$ & 3,64 & 1,07 & $-0,111$ & $-0,616$ \\
\hline Samimi Davranış & 3,86 & 1,04 & & \\
\hline Duygusal Emek & 3,13 & 1,17 & & \\
\hline
\end{tabular}

YD: Yüzeysel Davranış; DD: Derinlemesine Davranış; SD: Samimi Davranış

Tablo 4: Duygusal Emek İfadelerine İlişkin Tanımlayıcı İstatistikler

Duygusal emek ölçeğinin alt boyutlarının ortalaması șu șekildedir; "yüzeysel davranıș" 2,22, "derinlemesine davranış" 3,30, "samimi davranış" 3,86'dır. Duygusal emek davranıșının genel ortalaması ise 3,13'dür.

Ortalamalar incelendiğinde, katılımcıların duygusal emek davranıșlarının orta düzeyde olduğu görülmektedir. Alt boyutlar bazında ortalamalar incelendiğinde katılımcıların yüzeysel davranışlarının düşük düzeyde; derinlemesine davranış ve samimi davranışın ise orta düzeyde olduğu görülmektedir.

Aynı zamanda Tablo 4'de ifadelere ilişkin basıklık (kurtosis) ve çarpıklık (skewness) değerleri gösterilmektedir. Basıklık ve çarpıklık değerleri -2 ile +2 arasında değişmesi gerekmektedir (Kline, 2015). Tablo 4'de görüldüğü üzere, basıklık değerleri 1.058 ile 1.113 arasında ve çarpıklık değerleri de -1.128 ile 0,959 arasındadır. Her iki değerde kabul edilebilir aralıkta olduğu için verilerin normal dağılım gösterdiği kabul edilmektedir. 


\begin{tabular}{|c|c|c|c|c|}
\hline İş Stresi İfadeleri & $\begin{array}{l}\text { İfadelere } \\
\text { İlişkin } \\
\text { Ortalama } \\
\text { Değerler }\end{array}$ & $\begin{array}{l}\text { Standart } \\
\text { Sapma }\end{array}$ & $\begin{array}{l}\text { Basıklık } \\
\text { Değerleri }\end{array}$ & $\begin{array}{l}\text { Çarpıklık } \\
\text { Değerleri }\end{array}$ \\
\hline $\begin{array}{l}\text { ES1: "İşim nedeniyle huzursuz } \\
\text { ya da sinirli hissettiğim } \\
\text { olmuştur." }\end{array}$ & 3,59 & 1,11 & $-0,040$ & $-0,774$ \\
\hline $\begin{array}{l}\text { ES2: “İşim beni olması } \\
\text { gereğinden daha fazla rahatsız } \\
\text { ediyor." }\end{array}$ & 2,28 & 1,10 & $-0,137$ & 0,723 \\
\hline $\begin{array}{l}\text { ES3: "İşimin beni çıldırttığı çok } \\
\text { zaman olmuştur." }\end{array}$ & 2,66 & 1,23 & $-0,859$ & 0,280 \\
\hline $\begin{array}{l}\text { ES4: “Bazen işimi } \\
\text { düşündüğümde, göğsümde bir } \\
\text { sıkıntı hissediyorum." }\end{array}$ & 2,23 & 1,13 & $-0,208$ & 0,742 \\
\hline Endişe Stresi & 2,69 & 1,14 & & \\
\hline $\begin{array}{l}\text { ZS1: "Çok fazla işim ve bu işleri } \\
\text { yapacak çok az zamanım var." }\end{array}$ & 2,73 & 1,22 & $-0,838$ & 0,245 \\
\hline $\begin{array}{l}\text { ZS2: "Bazen evde telefonun } \\
\text { çalmasından arama işle ilgili } \\
\text { olabilir diye korkuyorum." }\end{array}$ & 2,21 & 1,18 & $-0,712$ & 0,093 \\
\hline $\begin{array}{l}\text { ZS3: "Sanki hiç izin } \\
\text { kullanmamış gibi } \\
\text { hissediyorum." }\end{array}$ & 2,90 & 1,27 & -1.008 & 0,137 \\
\hline $\begin{array}{l}\text { ZS4: "Şirketimde benimle aynı } \\
\text { seviyede çalışan birçok insan } \\
\text { işin gereklilikleri yüzünden } \\
\text { tükenmiştir." }\end{array}$ & 2,74 & 1,19 & $-0,821$ & 0,178 \\
\hline Zaman Stresi & 2,64 & 1,21 & & \\
\hline İş Stresi & 2,66 & 1,17 & & \\
\hline
\end{tabular}

ES: Endişe Stresi; ZS: Zaman Stresi

Tablo 5. İş Stresi İfadelerine İlișkin Tanımlayıcı İstatistikler

İş stresi ölçeğinin alt boyutlarının ortalaması şu șekildedir; "endişe stresi" 2,69, "zaman stresi" 2,64'tür. İș stresinin genel ortalaması 2,66'dır.

Ortalamalar incelendiğinde, katılımcıların iş stresinin düşük düzeyde olduğu görülmektedir. Alt boyutlar bazında ortalamalar değerlendirildiğinde katılımcıların hem zaman stresi hem de endișe stresinin düşük düzeyde olduğu görülmektedir.

Aynı zamanda Tablo 5'de ifadelere ilişkin basıklık ve çarpıklık değerleri gösterilmektedir. Basıklık ve çarpıklık değerleri -2 ile +2 arasında değişmesi gerekmektedir (Kline, 2015). Tablo 5'de görüldüğü üzere, basıklık değerleri -0,040 ile 1,008 arasında ve çarpıklık değerleri de $-0,774$ ile 0,742 arasındadır. Her iki değerde kabul edilebilir aralıkta olduğu için verilerin normal dağılım gösterdiği kabul edilmektedir.

\subsection{Değişkenler Arası İlişkiler}

Bu araştırmada duygusal emek ile iş stresi arasında ilişki olabileceği ve duygusal emeğin boyutları olan yüzeysel davranış, derinlemesine davranış ve samimi davranış ile 
iş stresi boyutları olan zaman stresi ve endişe stresi arasında ilişki olacağı beklenmektedir.

$\mathrm{Bu}$ bağlamda, ilişkilerin tespit edilmesi için korelasyon analizinden faydalanılacaktır. Korelasyon analizi, değişkenler arasındaki birlikte değişim ilişkisini ve ilişkilerin yönünü göstermek için kullanılan bir analiz yöntemidir (Yazıcıoğlu \& Erdoğan, 2007).

Duygusal emek ile iş stresi arasında ilişki olabileceği görüşünden hareketle araştırmanın hipotezi şu șekilde kurulmuştur;

$H_{1}$ : Duygusal emek ile iş stresi arasında iliş̧i vardır.

\begin{tabular}{|c|c|c|c|c|c|c|c|}
\hline & $\begin{array}{l}\text { Duygusal } \\
\text { Emek }\end{array}$ & $\begin{array}{l}\text { Yüzeysel } \\
\text { Davranıș }\end{array}$ & $\begin{array}{l}\text { Derinlemesine } \\
\text { Davranıș }\end{array}$ & $\begin{array}{l}\text { Samimi } \\
\text { Davranıș }\end{array}$ & $\begin{array}{l}\text { İş } \\
\text { Stresi }\end{array}$ & $\begin{array}{l}\text { Zaman } \\
\text { Stresi } \\
\end{array}$ & $\begin{array}{l}\text { Endisse } \\
\text { Stresi }\end{array}$ \\
\hline Duygusal Emek & 1 & & & & & & \\
\hline $\begin{array}{l}\text { Yüzeysel } \\
\text { Davranış }\end{array}$ & $0,686^{* *}$ & 1 & & & & & \\
\hline $\begin{array}{l}\text { Derinlemesine } \\
\text { Davranış }\end{array}$ & $0,743^{* *}$ & $0,141^{* *}$ & 1 & & & & \\
\hline $\begin{array}{l}\text { Samimi } \\
\text { Davranış }\end{array}$ & $0,273^{* *}$ & $-0,316^{* *}$ & $0,259^{* *}$ & 1 & & & \\
\hline İş Stresi & $0,138^{*}$ & $0,181^{* *}$ & 0,027 & $-0,024$ & 1 & & \\
\hline Zaman Stresi & $0,141^{* *}$ & $0,168^{* *}$ & 0,034 & 0,001 & $0,875^{* *}$ & 1 & \\
\hline Endişe Stresi & 0,104 & $0,153^{* *}$ & 0,014 & $-0,041$ & $0,882^{* *}$ & $0,545^{* *}$ & 1 \\
\hline
\end{tabular}

**: Korelasyon 0.01 düzeyinde anlamlı *: Korelasyon 0.05 düzeyinde anlamlı

Tablo 6: Duygusal Emek ile İş Stresi Arasındaki İlişkiye Yönelik Korelasyon Analizi Sonuçları

Duygusal emek ile iş stresi arasındaki ilişkiye yönelik korelasyon analizi Tablo 6'da gösterilmektedir. Tablo 6'da görüldüğü üzere, duygusal emek ile iş stresi arasında $(\mathrm{r}=0,138)$ pozitif ve anlamlı bir ilișki vardır. Bu doğrultuda ' $H_{1}$ : Duygusal emek ile iş stresi arasında ilișki vardır.' hipotezi desteklenmiștir.

Aynı zamanda Tablo 6'da duygusal emek ile boyutları olan yüzeysel davranış, derinlemesine davranış ve samimi davranış arasındaki ilişsiler de yer almaktadır. Duygusal emek ile yüzeysel davranış $(r=0,686)$, derinlemesine davranış $(r=0,743)$ ve samimi davranış $(r=0,273)$ arasında pozitif ve anlamlı bir ilişki vardır. Yüzeysel davranış ile derinlemesine davranış arasında $(r=0,141)$ pozitif ve anlamll, samimi davranış ile $(r=-$ $0,316)$ negatif ve anlamlı bir ilişki vardır. Derinlemesine davranış ve samimi davranış arasında ise $(\mathrm{r}=0,259)$ pozitif ve anlamlı bir ilișki vardır.

İș stresi ve iş stresi alt boyutları olan zaman ve endișe stresi arasındaki ilişkiler yine Tablo 6'da yer almaktadır. İş stresi ile zaman stresi $(r=0,875)$ ve endișe stresi $(r=0,882)$ arasında pozitif ve anlamlı bir ilişki vardır. Bunun yanı sıra, endişe stresi ile zaman stresi arasında da $(\mathrm{r}=0,545)$ pozitif ve anlamlı bir ilişki vardır.

Aynı zamanda, Tablo 6'da görüldüğü üzere, duygusal emek ile iş stresinin boyutlarından zaman stresi arasında $(\mathrm{r}=0,141)$ pozitif ve anlamlı bir ilișki varken endișe stresi arasında ise anlamlı bir ilişki gözlemlenmemiştir.

Duygusal emek boyutları ile iş stresi boyutları arasında ilişki olabileceği görüşünden hareketle araştırmanın alt hipotezi şu şekilde kurulmuștur.

$H_{1 a}$ : Duygusal emeğin boyutları (yüzeysel davranış, derinlemesine davranış ve samimi davranış) ile iş stresi boyutları (zaman stresi ve endișe stresi) arasında ilişki vardır. 
Tablo 6'da görüldüğü üzere, duygusal emeğin boyutlarından olan yüzeysel davranış ile iş stresi arasında $(r=0,181)$ anlamlı ve pozitif ilişki vardır. Aynı zamanda, yüzeysel davranıș ile zaman stresi $(r=0,168)$ ve endișe stresi arasında $(r=0,153)$ pozitif ve anlamlı ilişkiler vardır.

Yine Tablo 6'da görüldüğü üzere, duygusal emeğin boyutları olan derinlemesine davranış ve samimi davranış ile iş stresi ve iş stresi boyutları olan zaman stresi ve endişe stresi arasında anlamlı ilişkiler gözlemlenmemiştir.

Bu doğrultuda 'Hı: Duygusal emeğin boyutları (yüzeysel davranış, derinlemesine davranış ve samimi davranış) ile iș stresi boyutları (zaman stresi ve endișe stresi) arasında ilişki vardır.' hipotezi kısmen desteklenmiștir.

\section{Araştırmanın Sonucu, Kısıtları ve Öneriler}

Hizmet sektöründe rekabetin ve müşterilerin beklentilerinin arttığı buna paralel hizmet kalitesinin hızla yükseldiği bir ortamda, örgütler varlıklarını sürdürmeye çalışmaktadır. Başarılarını sürdürülebilir kılmak isteyen örgütler, rakiplerinden daha iyi olabilmek, örgüt stratejilerine uygun hedefleri yakalayabilmek için iş görenlerin duygu yönetiminin önemini kavramışlardır.

Bir başka ifadeyle, günümüzde müşteri memnuniyeti kavramı örgütler için önemli başarı kriterlerinden biridir. Bunun yanı sıra, hizmet sunumu sırasında örgütün amaçlarına uygun olarak iş görenin örgütü ne kadar iyi ve doğru temsil ettiği önemlidir. $\mathrm{Bu}$ nedenle örgütler, iş görenin duygu ve davranışlarının doğru yönetilmesinin müşteri memnuniyeti üzerindeki önemini fark etmişler ve gösterim kuralları belirlemişlerdir. Dolayısıyla iş görenlerin hizmet sunumları sırasında kendi hissettikleri duygularına göre değil örgütün belirlediği gösterim kurallarına uygun davranmaları beklenmektedir. Bu noktada duygusal emek kavramı ortaya çıkmaktadır.

İş görenlerden gerçekleștirilmesi beklenen duygusal emek davranışının iş görenler üzerinde olumsuz çıktıları söz konusudur. Bu olumsuz çıtılırdan biri iş stresidir. Dolayısıyla duygusal emek davranışı ile iş stresi arasında ilişki olacağı beklenmektedir. Özellikle müșteriler ile birebir etkileşimde bulunan iş görenlerin üzerindeki iş stresinin bireysel, fiziksel, psikolojik ve örgütsel olumsuz etkileri olabilecektir. Bu nedenle örgütlerin belirlediği amaçlara ulaşabilmesi için, iş görenlerin yaşadığı iş stresinin azaltılması ve yönetilmesi gerekmektedir.

Dolayısıyla bu çalışmanın amacı duygusal emek ile iş stresi arasındaki ilişkiyi incelemektir. Araştırmada bağımsız değişken yüzeysel davranış, derinlemesine davranış ve samimi davranıştan oluşan duygusal emek iken bağımlı değişken ise zaman stresi ve endișe stresinden oluşan iș stresidir. Çalıșmanın bir diğer amacı ise aynı zamanda duygusal emek boyutları (yüzeysel davranıș, derinlemesine davranış ve samimi davranış) ile iş stresi boyutları (zaman stresi ve endişe stresi) arasındaki ilişkiyi de incelemektir.

Bu çalışmada, örneklem olarak bir kamu kuruluşu olan belediye seçilmiştir. Araștırmanın belediyede yapılmasının nedeni duygusal emek üzerine yapılan çalışmaların daha çok özel sektör üzerinde yapılmış olduğunun görülmüş olmasıdır. Fakat günümüzde kamu kurumlarında da müşteri memnuniyeti diye adlandırılan vatandaş memnuniyetinin önem kazanması, kamu çalışanlarının da duygusal emek davranışı göstermesi beklenilmesi nedeniyle bu çalışmanın literatüre katkı sağlaması beklenmektedir.

Araştırmanın bulguları genel olarak değerlendirildiğinde katılımcıların çoğunu kadınlar ve evliler oluşturmaktadır. Ayrıca araştırmaya katılan iş görenlerin çoğunluğu 41-50 yaş aralığında, çocuk sahibi, çalışan pozisyonunda ve çalışma hayatı kıdemleri 2130 yıl aralığında, mevcut yönetici ile çalışma süresi 4-5 yıl aralığında, kurum kıdeminin ise 8 ve üzeri yıl olduğu görülmüştür. 
Yapılan bu araştırmanın sonucuna göre duygusal emek ile iş stresi arasında pozitif ve anlamlı bir ilişki vardır. Rekabet baskısı altındaki örgütler müşteri memnuniyetini arttırabilmek için iş görenlerin uyması gereken gösterim kurallarını belirlemişlerdir. İş görenlerin hizmet sunumları sırasında hissetmedikleri bu duyguları hissediyormuş gibi göstermeleri, yoğun bir şekilde duygusal uyumsuzluk ve çatışma yaşamalarına, bir başka ifadeyle, iş stresine neden olmaktadır. Bu bağlamda, duygusal emek ile iş stresi arasında ilişki olduğu söylenebilmektedir. Bir başka ifadeyle, iş görenin göstermiş olduğu duygusal emek davranışı ile iş stresi arasında pozitif yönlü anlamlı bir ilişkinin olduğu bu çalışmanın sonucudur. Pugliesi (1999) \& Akdu ve Akdu (2016) yapmış oldukları çalışmalar da bu sonucu desteklemektedir.

$\mathrm{Bu}$ çalışmanın bir diğer sonucu ise duygusal emeğin boyutlarından olan yüzeysel davranış ile iş stresi ve iş stresi boyutları olan endişe ve zaman stresi arasında anlamlı ve pozitif ilişki olduğudur. İş görenlerin davranışlarını örgütün beklentilerine uygun hale getirme (yüzeysel davranış) sürecinde, rollerle kişilik özelliklerinin uyuşmaması rol çatışması yaşamalarına neden olmaktadır. Yaşadığı rol çatışması iş göreni olumsuz etkilemekte ve endişe stresinin artmasına yol açmaktadır. Bunun yanı sıra, iş görenin örgüt hedeflerine uygun olarak zaman baskısı altında müșteri memnuniyeti sağlayacak şekilde çalışma zorunluluğunun olması da zaman stresi yaşamasına neden olmaktadır. Diğer bir ifadeyle, iş görenin yüzeysel davranıșındaki değișimlere paralel olarak iș stresi ve iş stresinin boyutları olan endișe ve zaman stresi de yaşamaları beklenmektedir. Karakaş \& Gökmen (2018), Sohn vd. (2018), Özgün (2015), Yoon \& Kim (2013) yapmış oldukları çalışmalar da bu sonucu desteklemektedir.

Duygusal emeğin boyutları olan derinlemesine davranış ve samimi davranış ile iş stresi ve iş stresi boyutları olan zaman ve endișe stresi arasında anlamlı bir ilișki olmadığı bu çalışmanın bir başka sonucudur. İş görenin örgütün beklentilerine uygun olarak duygularını değiştirmesi (derinlemesine davranış) sürecinde iş gören duygusal çatışma ve zaman baskısı hissetmemekte ve endișe ve zaman stresi yaşamamaktadır. Aynı zamanda iş görenlerin örgütün kendisinden beklediği davranışları gerçekten hissederek sergilemeleri (samimi davranış) sonucunda herhangi bir baskı hissetmediklerinden endişe ve zaman stresi yaşamamaktadır. Sohn vd. (2018) yapmış oldukları çalıșma da bu sonucu desteklemektedir.

$\mathrm{Bu}$ çalışmada elde edilen verilerin, belediyelerdeki iş gücünün öneminin kavranmasına ve etkin bir şekilde yönetilmesine katkı sağlayacağı düşünülmektedir. Bu doğrultuda çalışmada, sektör uygulayıcılarına, iş görenlere ve araştırmacılara yönelik bazı önerilerde bulunulmuştur.

Bu çalışmanın sonuçlarına göre, kamu kurumlarında duygusal emeğin önemi ile ilgili eğitimler düzenlenebilir. Eğitimlerde, iş görenin iş stresi yaşamadan çalışabilmesi için, hizmet süresince rol yapma davranıșını azaltacak şekilde duyguların yönetilmesi ve içselleștirilmesi ile ilgili yöntemler öğretilebilir ve geliștirilebilir. Ayrıca bu eğitimler, iș görenlerin örgütsel özdeşleşmesini sağlayabilecek ve bağlılıklarını arttırabilecek motive edici sosyal aktivitelerle desteklenebilir.

Aynı zamanda, duygusal emeğin yoğun kullanıldığı pozisyonlara uygun vasıflara sahip iş görenler istihdam edilmelidir. Bu şekilde iş görenlerin örgütün davranış kurallarını benimsemesi ve kendi duyguları ile örgütün beklediği duygu gösterimlerini bütünleştirerek daha fazla derinlemesine ve samimi davranış göstermesi sağlanmalıdır. Başka bir ifadeyle, iş görende duygusal uyumsuzluk ve duygusal çatışma yaratacak yüzeysel davranıșı ve iș stresini azaltarak, örgütün verimliliğini ve hedeflerine ulașmasını olumsuz etkileyecek durumların önüne geçilmelidir.

Özellikle yöneticiler duygusal emek hakkındaki yönetsel becerilerini arttırarak, iş stresini azaltacak örgütsel stratejiler geliştirmeli ve iş görenlerin duygusal dünyaları ile ilgili olumsuz değişiklikler takip edilmelidir. Bunun yanı sıra, iş görenlerin iş stresi 
yaşadıklarını fark ettikleri zaman danışmanlık hizmeti alabilecekleri profesyonel uzmanların bulunduğu birimler oluşturulmalıdır. Ayrıca iş görenlerin çalışma arkadaşlarından alacakları sosyal desteğin, duygusal emeğin olumsuz etkilerini azaltacağı gözlemlendiğinden, iş görenlerin birbirleri ile iletişim kurabilecekleri ortamlar oluşturmalıdır.

$\mathrm{Bu}$ çalışmanın sonuçları iş görenler açısından değerlendirildiğinde, iş görenlerin, hizmet sektöründe duygusal emek davranışı göstereceklerinin ve bunun sonucunda iş stresine maruz kalacaklarının farkında olarak, kendilerini motive etmeleri ve kurumun hedeflerine uygun kendilerinden beklenen davranış şekillerini öğrenerek bu davranışları içselleștirmeleridir. Bunun yanı sıra, iş görenlere derinlemesine ve samimi davranış gösterme yeteneklerinin gelişmesini sağlayacak zaman ve endișe stresini azaltacak yöntemleri öğrenecekleri eğitimlere katılmaları önerilebilir.

$\mathrm{Bu}$ çalışmanın ortaya koyduğu sonuçlar ile literatüre belli bir katkı sağlamaya çalışılmış olmasına karşın bazı kısıtları bulunmaktadır Yapılan bu çalışmanın sadece İstanbul'da bir ilçe belediyesi iş görenleri üzerine gerçekleștirilmiş olması araștırmadaki bulguların diğer belediyelerdeki iş görenlerin görüşlerini yansıtacağı anlamına gelmemektedir. Diğer bir ifadeyle, araştırmada elde edilen sonuçlar, sadece araştırmaya katılan belediye iş görenlerinin oluşturduğu sınırlı örneklem için geçerli olacaktır. Ayrıca belediye iş görenlerinin çalışma temposunun yoğunluğu ve kısıtll zaman nedeniyle veri toplama sürecinde sadece anket yöntemi kullanılmıştır. Karma veri toplama yöntemleri kullanılarak yapılacak çalışmalarda, geçerlilik ve güvenilirlik açısından çok daha sağlıklı sonuçlar elde edilebilecektir.

Çalışma sadece İstanbul ilinde bir ilçe belediyesinde yapılmıştır. Daha sonra yapılacak çalışmaların farklı il ve ilçe belediye iş görenleri ile yapılması veya farklı meslek gruplarında, özel sektör ve kamu sektörü karşılaștırması veya farklı bölgelerdeki kamu kurumlarında karşılaştırılmalar yapılabilir. Bunun yanı sıra, belediye iş görenleri ile birlikte vatandaşların da araştırmaya katılması ile iş görenlerin hizmet sunarken duygusal emek davranışlarının ve iş stresi düzeylerinin vatandaşlar üzerindeki etkileri belirlenebilir. Diğer taraftan; örgüt kültürü, liderlik, kişilik, motivasyon, iş-yaşam dengesi, örgütsel özdeşleşme, örgütsel bağlılık, duygusal zekâ gibi konuların araștırmacılar tarafından incelenerek sosyal bilimler alanına katkı sağlamaları önerilmektedir.

Sonuç olarak, iş görenlerin örgütlerin belirlediği gösterim kurallarını içselleştirerek daha az iş stresi yaşayabilecekleri söylenebilir. Bu durumun iş görenlerin bireysel ve örgütsel yaşamına olumlu yansımaları olabilecektir.

\section{KAYNAKÇA}

AKDU, U. \& AKDU, S. (2016). Duygusal emek ve iş stresinin tükenmişlik üzerindeki etkileri: Profesyonel turist rehberleri üzerinde bir araştırma. Journal of International Social Research, 9(47).

ALTUNTAȘ, E. (2003). Stres yönetimi. İstanbul: Alfa Yayınları.

ASHFORTH, B. E. \& HUMPHREY, R. H. (1993). Emotional labor in service roles: The influence of identity. Academy of Management Review, 18(1), 88-115.

ANTONOVA, E. (2016). Occupational Stress, Job Satisfaction, and Employee Loyalty in Hospitality Industry: A Comparative Case Study of Two Hotels in Russia (Yayınlanmamış Yüksek Lisans Tezi). Modul Vienna University, Viyana.

BABATUNDE, A. (2013). Occupational stress: A review on conceptualizations, causes and cure. Economic Insights - Trends and Challenges, 2(3), 73-80. 
BAĞCI, Z. (2015). Duygusal emeğin iş performansı üzerindeki etkisi: Denizli ilinde hizmet sektöründe görgül bir araştırma. Kafkas Üniversitesi Íktisadi ve İdari Bilimler Fakültesi Dergisi, 6(10), 71- 75.

BASIM, H. N., \& BEĞENIRBAȘ, M. (2012). Çalışma yaşamında duygusal emek: bir ölçek uyarlama çalışması. Yönetim ve Ekonomi: Celal Bayar Üniversitesi İktisadi ve İdari Bilimler Fakültesi Dergisi, 19(1), 77-90.

BEĞENIRBAȘ, M. \& MEYDAN, C. H. (2012). Duygusal emeğin örgütsel vatandaşlık davranıșıyla ilișkisi: Öğretmenler üzerinde bir araştırma. Gazi Üniversitesi İktisadi ve İdari Bilimler Fakültesi Dergisi, 14(3), 159-181.

BROTHERIDGE, C. M. \& GRANDEY, A. A. (2002). Emotional labor and burnout: comparing two perspectives of "People work". Journal of Vocational Behavior, 60(1), 17 39.

CHU, K. H. L. (2002). The effects of emotional labor on employee work outcomes. (Unpublished Doctoral Dissertation). Virginia Polytechnic Institute and State University, Virginia.

CÔTÉ, S. \& MORGAN, L. M (2002). A longitudinal analysis of the association between emotion regulation, job satisfaction, and intentions to quit. Journal of Organizational Behavior, 23(8), 947-962.

CRONBACH, L. J. (1951). Coefficient alpha and the internal structure of tests. Psychometrika, 16(3), 297-334.

CÜCELOĞLU, D. (1991). Insan ve davranıss. İstanbul: Evrim Matbaacilık.

DIEFENDORFF, J. M., CROYLE, M. H., \& GOSSERAND, R. H. (2005). The dimensionality and antecedents of emotional labor strategies. Journal of Vocational Behavior, 66(2), 339-357.

DIEFENDORFF, J. M. \& GOSSERAND, R. H. (2003). Understanding the emotional labor process: A control theory perspective. Journal of Organizational Behavior: The International Journal of Industrial, Occupational and Organizational Psychology and Behavior, 24(8), 945-959.

DURMUŞ, B., YURTKURU, S.E. \& ÇINKO M. (2011). Sosyal bilimlerde SPSS'le veri analizi. 4. Baskı. İstanbul: Beta Yayıncılık.

DURNA, U. (2006). Üniversite öğrencilerinin stres düzeylerinin bazı değiş̧enler açısından incelenmesi. Atatürk Üniversitesi İktisadi ve İdari Bilimler Fakültesi Dergisi, 319-343.

ERKOÇ, Z., (2006). Insan kaynakları yönetimi ve kalite yönetim sistemi terimler sözlügü. İstanbul: Alfa Yayınları.

EROĞLU, E. (2010). Örgütsel iletişimin iş görenlerin duygu gösterimlerinin yönetimine olan etkisi. Selçuk Üniversitesi İletişim Fakültesi Akademik Dergisi, 6(3), 1833.

FIELDS, D. L. (2002). Taking the measure of work: a guide to validated scales for organizational research and diagnosis. Thousand Oaks, CA: Sage Publications.

GALL L. A., (2006), Anksiyete ve kaygı, (İ. Yerguz, Çev.). Ankara: Dost Kitabevi, Nisan, Birinci Baskı.

GRANDEY, A. A. (2000). Emotional regulation in the workplace: A new way to conceptualize emotional labor. Journal of Occupational Health Psychology, 5(1), 95.-117.

GRANDEY, A. A. (2002). When "the show must go on": Surface acting and deep acting as determinants of emotional exhaustion and peer-rated service delivery. Academy of Management Journal, 46(1), 86-96.

GRIFFITS, A. (2010). Work organization \& stress. World Health Cox, Tom: Organization, Protecting Workers' Health Series, 3.

GÜNEY, S. (2016). Davranış bilimleri. Ankara: Nobel Yayınevi. 
HOCHSCHILD, A.R, (1983). The managed hearth: commercialization of human feeling. Berkeley: University of California Press.

JAMAL, M. (1999). Job stress and employee well-being: A cross-cultural empirical study. Stress \& Medicine, 15, 153-158.

JUDGE, T.A. \& COLQUITT, J. A. (2004). Organizational justice and stress: The mediating role of work-family conflict. Journal of Applied Psychology, 89(3), 395-404.

JUNG, H. S. \& YOON, H. H., (2014). Moderating role of hotel employees: Gender and job position on the relationship between emotional intelligence and emotional labor. International Journal of Hospitality Management, 43, 47-52.

KARAKAȘ, A., TÖSTEN, R., KANSU, V., \& AYDIN, A. S. (2016). Öğretmenlerin duygusal emek davranışlarının işdoyumlarına etkisi. Elektronik Sosyal Bilimler Dergisi, 15(56), 177-188.

KARAKAŞ, A. (2017). Duygusal emek, tükenmişlik ve işten ayrılma niyeti arasındaki ilişki: Otel işletmesi çalışanları üzerine bir araştırma. Işsletme Araştırmaları Dergisi, 9(1), 80-112.

KARAKAȘ, A. \& GÖKMEN, G. (2018). Kamu çalıșanlarında iș tatmini, duygusal emek ve iş stresi: Konya'da bir araştırma. Bolu Abant İzzet Baysal Üniversitesi Sosyal Bilimler Enstitüsü Dergisi, 18(3), 99-127.

KAYA, U. \& ÖZHAN, Ç. K. (2012). Duygusal emek ve tükenmişlik ilişkisi: Turist rehberleri üzerine bir araştırma. Çalışma İlişkileri Dergisi, 3(2), 109-130.

KAYA, U. \& SERÇEOĞLU, N. (2013). Duygu işçilerinde işe yabancılaşma: Hizmet sektöründe bir araştırma. Çalışma ve Toplum, 36(1), 311-346.

KLINE, R. B. (2015). Principles and practice of structural equation modeling. Guilford Publications.

KOÇOĞLU, M. (2014). Cynicism as a mediator of relations between job stress and work alienation: A study from a developing country-Turkey. Global Business and Management Research, 6(1), 24.

LANDRUM, B., KNIGHT, D.K. \& FLYNN, (2011). The impact of organizational stress and burnout on client engagement. Journal of Substance Abuse Treatment, 42(2), ss. 222-230.

LEE, J. J. \& OK, C. (2012). Reducing burnout and enhancing job satisfaction: critical role of hotel employee's emotional intelligence and emotional labor.

International Journal of Hospitality Management, 31(4), 1101-1112.

MATTESON, M. L. \& MILLER, S. S., (2012). Emotional labor in librarianship: A research agenda. Library and Information Science Research, 34 (3), 176-183.

MENGENCI, C. (2015). İș tatmini, duygusal emek ve tükenmişlik ilişkilerinin belirlenmesi. Ege Akademik Bakış, 15(1), 127-139.

MORRIS, J. A. \& FELDMAN, D. C. (1996). The dimensions, antecedents, and consequences of emotional labor. Academy of Management Review, 21(4), 986-1010.

NAIR, P. K. (2007). A Path Analysis of Relationships Among Job Stress, Job Satisfaction, Motivation to Transfer, and Transfer of Learning: Perceptions of Occupational Safety and Health Administration Outreach Trainers. Unpublished Doctoral Dissertation, Texas A\&M University, College Station.

NETEMEYER, R. G., MAXHAM, J. G., \& PULLIG, C. (2005). Conflicts in the workfamily interface: Links to job stress, customer service employee performance, and customer purchase intent. Journal of Marketing, 69(2), 130-143.

ONBAŞIOĞLU, M. (2004). Stresle baş etmede zihinsel yöntemler. Türk Psikoloji Bülteni, 10(34-35), 103-127.

ORAL, L. \& KÖSE, S. (2011). Hekimlerin duygusal emek kullanımı ile iş doyumu ve tükenmişlik düzeyleri arasındaki ilişkiler üzerinde bir araştırma. Süleyman Demirel Üniversitesi İktisadi ve İdari Bilimler Fakültesi Dergisi, 16(2),463-492. 
ÖNDER, D.G. (1991). Yönetsel zaman ve verimlilik ilişkisinde yeni bir perspektif. Ankara: MPM Yayınları.

ÖRNEK, A. Ş. \& AYDIN, Ş. (2008). Kriz ve stres yönetimi. Detay Yayıncılık.

ÖZGÜN, A. (2015). Duygusal emek davranışının işs stresi üzerindeki etkisi: eğitim sektöründe bir uygulama. (Yayınlanmamış Yüksek Lisans Tezi). Dokuz Eylül Üniversitesi Sosyal Bilimler Enstitüsü İșletme Anabilim Dalı, İzmir.

ÖZKAN, G. (2011). Duygusal emek gerektiren mesleklerde örgütsel iletişim doyumunun duygusal emeğe bağlı iş doyumuna etkisi: Çă̆rı merkezlerinde bir uygulama örneği, (Yayımlanmamış Yüksek Lisans Tezi). Eskișehir: Anadolu Üniversitesi Sosyal Bilimler Enstitüsü.

PARKER, D. F. \& DECOTIIS, T. A. (1983). Organizational determinants of job stress. Organizational Behavior and Human Performance, 32(2), 160-177.

PUGLIESI, K. (1999). The consequences of emotional labor: Effects on work stress, job satisfaction, and well-being. Motivation and Emotion, 23(2), 125-154.

ROSS, R. R. \& ALTMAIER, E. M. (1994). Intervention in occupational stress: a handbook of counselling for stress at work. Sage.

SCHERMERHORN, J. R (1989). Management for productivity. New York: John Willey and Sons.

SCHMIDT, K. H. \& DIESTEL, S. (2014). Are emotional labour strategies by nurses associated with psychological costs? A cross-sectional survey. International Journal of Nursing Studies, 51(11), 1450-1461.

SOHN, B. K., PARK, S. M., PARK, I. J., HWANG, J. Y., CHOI, J. S., LEE, J. Y., \& JUNG, H. Y. (2018). The relationship between emotional labor and job stress among hospital workers. Journal of Korean Medical Science, 33(39), 1-10.

THEODOSIUS, C. (2008). Emotional labour in health care: The unmanaged heart of nursing. Routledge.

TOPRAK, L., SERÇEK, G. Ö., \& KARAKAŞ, A. The relation between emotional labor job burnout and intention to turnover a research on travel agency workers. Economy and Sociology, (3), 47-57.

TUTAR, H. (2014). Örgütsel psikoloji. Ankara: Detay Yayıncılık.

WEISS, H. M. \& CROPANZANO, R. (1996). Affeetive events theory: A theoretical discussion of the structure, causes and consequences of affective experiences at work. Research in Organizational Behavior, 18, 1-79.

YANG, F. H. \& CHANG, C. C. (2008). Emotional labour, job satisfaction and organizational commitment amongst clinical nurses: A Questionnaire Survey.

International Journal of Nursing Studies, 45(6), 879-887.

YAZICIOĞLU, Y. \& ERDOĞAN, S. (2007). SPSS uygulamalı bilimsel araștırma yöntemleri. Detay Yayıncılık

YİRIK, Ş., ÖREN, D., \& EKICI, R. (2014). Dört ve beş yıldızlı otel işletmelerinde çalışan personelin örgütsel stres ve örgütsel tükenmişlik düzeyleri arasındaki ilișkilerin demografik değişkenler bazında incelenmesi. E-Journal of Yaşar University, 6223-6234.

YOON, S. L., \& KIM, J. H. (2013). Job related stress, emotional labor, and depressive symptoms among Korean nurses. Journal of Nursing Scholarship, 45(2), 169 176.

YÜKSEL, İ., (2003). İș stresi, işe bağlılık ve iş doyumu arasındaki ilişkinin analizi: Teknisyenlere yönelik bir uygulama. Atatürk Üniversitesi İktisadi ve İdari Bilimler Dergisi, 17(1-2). 213- 224.

YÜRÜR, S. \& ÜNLÜ, A. G. O. (2011). Duygusal emek, duygusal tükenme ve ișten ayrılma niyeti ilişkisi. The Journal of Industrial Relations and Human Resources, 13(2). 
Hidayet Yıldız, Merve Koçoğlu Sazkaya, "Duygusal Emek ile İș Stresi İlișkisinin İncelenmesi: Kamu Çalıșanlarına Yönelik Bir Araştırma”, İstanbul Gelişim Üniversitesi Sosyal Bilimler Dergisi, 8 (1), Nisan 2021, ss. 29-50.

\section{Summary}

Today, the products and services that organizations offer to their customers are more and more similar. This necessitates the customer-oriented activities of the organizations. In particular, the fact that customer-oriented work in the service sector provides a significant competitive advantage requires employers to emotionally spend their labor while performing the tasks assigned to them. Therefore, organizations that plan to achieve customer satisfaction at the highest level are now face with the process managing the emotional labor of the employees. In this direction, organizations have determined the rules of emotional representation that will arouse positive emotions with their customers and expect employees to follow these rules. Emotional labor is expressed as the intense effort of the employee to show the emotion that the employees do not feel but the organization expects from them.

On the other hand, employees' intense emotional labor sometimes leads to negative consequences. One of these results is job stress. Job stress is a condition that has positive and negative characteristics as a result of the interaction between employee and working conditions. In other words, organizations aiming competitive advantage are looking for more expectations from employees in order to meet the increasing customer satisfaction criteria. This situation causes job stress for the employees. In this context, emotional labor behavior is seen as an important factor affecting job stress.

When the literature is examined, it is seen that although there are many studies conducted with private sector that are related to the relationship between emotional labor and job stress, there are not many studies conducted for public institutions. Therefore, this study is thought to contribute to the literature on the subject, especially for the public sector. Therefore, the aim of this study is to reveal the relationship between emotional labor behaviors (surface acting, deep acting and naturally felt emotion) and job stress (time stress and anxiety stress) of municipal employees.

This study was conducted on 347 white-collar workers working in a district municipality in Istanbul in 2019 to examine the relationship between emotional labor and job stress.

The independent variable of the research was emotional labor consisting of surface acting, deep acting and naturally felt emotion. The dependent variable was job stress, which consists of time stress and anxiety stress dimensions.

In order to determine the relationship between emotional labor and job stress, the following hypothesis $\mathrm{H}_{1}$ and the sub-hypothesis were established.

$H_{1}$ : There is a relationship between emotional labor and job stress.

$H_{1 a}$ : There is a relationship between the dimensions of emotional labor (surface acting, deep acting and naturally felt emotion) and job stress dimensions (stress of time and anxiety).

The scales used in the study were determined and validated after a detailed literature review. In this study, emotional labor scale was used. Emotional labor scale was developed by Diefendorff et al. (2005). And also in this study, the short form of the job stress scale was used. It was developed by Parker and Decotiis (1983).

The results of the study revealed that there is a positive and significant relationship between emotional labor and job stress. Thus, $H_{1}$ hypothesis is accepted. Additionally, there are positive and significant relationships between surface acting (one of the dimensions of emotional labor) and job stress and its dimensions which are time stress, anxiety stress respectively. However, deep acting and naturally felt emotions do not have significant relationships with job stress and its dimensions which are time stress and anxiety stress. Thus, Thus, $H_{1 a}$ hypothesis is partially accepted. 